\title{
Adjustment of the Curriculum of Gifted Student Madrasah through Designing The Curriculum Based System Credit Semester
}

\author{
Eko Supriyanto \\ University of Muhammadiyah Surakarta, Indonesia \\ es113@ums.ac.id
}

\begin{abstract}
Fewest type of services the specailly education for the gifted student in Indonesia because entire the school in Indonesia was conducted by curriculum normal include the school madrasah. The school of Madrasah was missleading use curriculum for gifted student so they suffer decline achievement the academic. Based on this condition, needed the curriculum that appropriate with abilities and character them there is Curriculum Based Credit Semester. This study aims to decribe way of adjustment the curriculum reguler into gifted student: curriculum based credit semester at the madrasah Indonesia. Method for gathering of data used interview and documentation. While the analysis of data used flow analysis. The result of the research are, first, adjustment the curriculum special for the gifted student through conversion sum duration hour teaching and learning curriculum normal into the curriculum based system credit semester (SKS), second that the curriculum based system credit semester very promote high academic achievement and avoid increasing fenomena underahievement. The curriculum based system cerdit semester appropriate with gifted student in the madrasah because be able adaptation with their learning style, interest learning and face them.
\end{abstract}

Key words: Curriculum based system credit semester, gifted student and underachievement

\section{INTRODUCTION}

The Reformation movement in Indonesia on Education area was more emphasis at empowering institutional through autonomy affirmation and enabling the students' existence. This movement in Indonesia was begun on 2014, for example through the increasing of many curriculum policies in school and Madrasah in Indonesia, one of the policy is the implementation of Semester Credit System (SCS) in the high school by the regulation of The Ministry of Education and Culture number 158/2014.

The policy of implementation SCS must be started with purposing structure of curriculum that based on regular curriculum 2006 or curriculum 2013.Based on theregulation, implementation SCS should be conducted conversion before that calculating price of time pocket system curriculum into a time system SCS. This demand becomes more important since curriculum structure that based on SCS will be implemented for the gifted student who need fast curriculum.

The Philosophy of provide services through SCS was increased because of demand, so that the instructional service should be equal implemented. The interpretation of equal is the student normal obtained the regular service instructional, while the gifted student also meet service instructional that appropriate with their habit, also for the slow learner [1]. Majority false establishment education in Indonesia is obtained the same instructional service for all students who have difference abilities, interest and intellectuals.

Although the implementation of SCS curriculum have been settling the year 2015/2016, but the application of this regulation still meeting many obstacles. The difficulty of implementation of SCS from aspect of the teachers hasn't pedagogy science and this obstacle more difficult because they are not ready for technical guidance model for SCS conversion in the Madrasah school. Therefore, this article has goal to discover the adjusmentof SCS curriculum model as effort to meet the gifted student of Madrasah has the high ability to establish education service. The basic of the Core theory that is used in the study is credit semester system from Mick Betts and Robin Smith by using unit hour regular per week (40 hours) divide total credit each semester to determine the value of SCS conversion. With the SCS curriculum will make possible for the gifted student to accomplish their study only 4 semesters [2]-[3]. By composing Curriculum of SCS Madrasah school can apply the equal principle and opportunity for learning their own character and fulfillingthe expectation.

In the application of SCS curriculum that using duration time of learning as long as 4 semesters will need management of special conversion, because this implementation must be removed price/value of hours duration teaching in class and assign of structured or independent. Therefore, it needs reference price of conversion special, so that learning load during the week does not give burden for the students' capacity, especially for the gifted students in Madrasah. The consideration to use engineering time of learning to maximizing student's achievement because it is one of the important factorsto determine the achievement [4]

The Curriculum, (Type and Meaning ofCurriculum)

Curriculum according to Herbert m. Klibard [5] was described that curriculum also mean as sum of range time of instructional implementation. The definition from Herbart emphasis on SCS that part of the curriculum structure, so it will be used in the research because it focus on structuring of curriculum in the range of distribution time learning that for allocation all subjects that obtained in the Madrasah Aliyah. 
Semester Credit System accordingto Permendikbud number 158/2014 article 1 give definition as form of conducting education who has students can make self choice of the load sum and subjects that will follow each semester, in the education institution appropriate with talent, interest and abilities or pace him. Menu curriculum must giving equality at least in the three aspects: equal opportunity, equal treatment and equal outcome [6]. SCS for the gifted students in the Madrasah Aliyahnot allow tonarrow indeed ignore opportunity learning because they must follow regular curriculum.

Requirement preparation SCS curriculum must become the part of enabling Madrasah institutionally and planning that supporting for the students in maximal opportunity to reach the best performance in academic [7].Preparing SCS curriculum for the gifted students need reference regular curriculum which is non SCS (curriculum 2006 or curriculum 2013) as basic for it proposing.

In the article 10 was described that every students of Madrasah Aliyah can (optional) master their study during 2 years. In order that require increasing fast curriculum all at once guarantee to fulfill the quality output [8]. This effort is very important to do because during the school only give $51 \%$ from iinstructional for execution internal problem of Madrasah [9].

In the point out Jenifer for the result quality of graduate agree with competence and development gifted potential, needed curriculum different so load learning menu in the curriculum appropriate with face, excellence and student ability. This point out more strengthened by Wendy Concklin [10]-[11]who preparing curriculum that is appropriate with the character of the gifted student can function to avoid the occurring of underachievement.

When it was agreed of credit standard that converted in the price sum minutes in the class or in the assignment that must done by the gifted student and teachers in external class, then designer curriculum must articulated sum hours that must be taken by the student for mastery the subject. Linked with articulation sum of these hours, E. Theodossin [12] divide between sum hours that must be done by teacher as tutor contact and sum hours that must be done by the students in the learning activities form that then call with student committed time or learning time.

The definition of articulation SCS in the student committed time perspective according to Mick Betts' opinon and Robin Smith [13] showed that the activities must be done by the students in learning subject always comprise with activities face to face with their teacher in the class, so the meaning of 5 SCS for the students should be done 5 hours face to face in the class plus 5 hours structure activities and 5 hours independent activities.

\section{METHOD}

The study used qualitative reasearch as study approach for resulting information of data deeply. The implementation of research conducted by following procedure that illustrated with the following steps:

Schema 1: procedures of research.

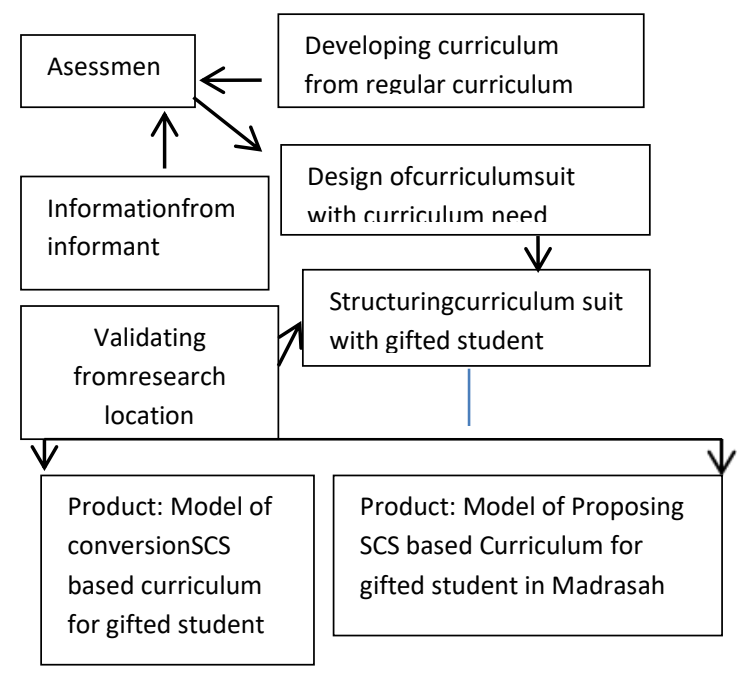

In these stages of modeling process of conversion SCS that resulted by this research, according to Jon, M. Pawlowski [14] required presence need analysis; there is need analysis of SCS curriculum of Madrasah for the gifted students. Need analysis conducted for purpose to avoid inappropriate between product and outcome expectation from madrasah [15].

The research location atMadrasah AliyahAmanatulUmmahPacetMojokerto regency East Java during 4 months. The location choice is in the boarding school for conducting research, because this boarding has dynamic and high innovation that needed for accommodation the students who identified as gifted students.

The analysis method use is interactive analysis from Huberman [16] so that deficiency of data can fulfill, because it is possible to take data conducting any time.To fulfill the quality of conversion guidance resulted, application standard ISO/IEC 19796 consist of three aspects, there are:1. description for quality approach, 2. the process model as reference classification and 3 . reference criteria for evaluation using.Three aspects

This study seek for implementation complement tangible for guidance for proposing SCS curriculum in Madrasah school that as one of method from many methods that is very needed for implementation SCS regulation that is mandated.

\section{RESULT}

Based onthe article 12 Permendikbud 158/2014 for Madrasah aliyah that have character of many subjects in all curriculum compared with curriculum of regular school, then very possible accord modification so that gifted student go home not very early evening. There are two methods to conducting conversion that is through modification SCS price that it before during allocation face to face in class 135 minutes became only 90 minutes for every 1 SCS price. The second method that is special 
for Madrasah that has boarding class, so instructional process conducted by two shifts that is regular teaching with regular curriculumby schedule regular period (morning - afternoon) and at night after night pray with special curriculum/enrichment curriculum. In the case of location research (Madrasah) showed that part of SCS curriculum that type of task structured conducting at night time until the regular teaching conducting on afternoon time without use learning time excessively in the afternoon time.

The Model of curriculum proposing based on SCS start calculate accumulation hours for all subjects from the regular curriculum for curriculum 2006 not for curriculum 2013 (option which choice), after sum all hours of subjects implemented conversion price package of subject's hour toward SCS. If the price of package of subject's hour be aware, for example in Madrasah curriculum was discovered 2 hoursadd every subject during six semesters then divide two. For example for religious subject that amount of hours during six semesters is 12 hours, then it conversion is 6 hours, for all the subjects.

The Implementation of SCS based on curriculum for Madrasah Aliyah at east Java using package conversion toward SCS for 2 hours, so package half price SCS. Because the subject in Madrasah school more comparative with subject's regular class, so conducted modification time duration learning before 45 minutes each meeting in class become 35 minutes, in order that the gifted students can go home earlier/not until night.

For the application of SCS based on curriculum in the Madrasah Aliyah at Pacet, Mojokertohas identify still acceleration class then the class doesn't go through time of learning until 3 years but using time learning two years. With this base package conversion toward SCS it duration changed faster than 10 minutes fewer from the regular learning time.

In Madrasah context thatusing SCS at PacetMojokerto, conducted conversion with adaptation and its time duration faster both in the semesters and in the learning time that must be taken. On the basis of this standard then reduce time earning demand was conducted for Madrasah School from 45 minute during this become 25 minute very proper.

\section{CONCLUSION}

The proposing curriculum model for Madrasah aliyah that is conducted by converting package price toward SCS with conversion every 1 SCS as much as 2 hours. The meaning of SCS in the Madrasah context that is gifted student can be chosen by themselvesfor learning loadappropriate with their ability. For Madrasah aliyahPacet have a lot of subjects after conducted conversion of package into SCS then forwarded with time reduction toward SCSbefore 135 minutes for three activities components SCS compact into 25 minutes so price of each 1 hour SCS have 75 minutes. This method very merit for avoid student go home later/evening time.
The proposing SCS base curriculum model that applied in Madrasah that for intendfor the gifted students that have learning style accelerated needed add again as activities courses compacting for found essential material. There for using proposing SCS based on curriculum in gifted class here add demanding for curriculum compact. Model for SCS based curriculum through five stages there is calculate sum of subject' hours all of subjects as long as year during in Madrasah Aliyah then divide two (value of conversion for package toward SCS). Therefore,to continue the distribution result of conversion hours of SCS to entire semesters, after each semester conducting totalitya lot SCS that will apply from the first semester until the last semester. If,it was found, then sum a lot SCS every semester divide sum learning day every weeks ( 5 or 6 days per week). If was find so build schedule appropriate with price SCS demand that will set out for every subject.

\section{REFERENCES}

[1] Smith, Emma. Analysing Underachievement in School. New York: Continuum 2005.

[2] Goas, Merrilyn. Teaching Secondary School Mathematics.NSW. Australia: Allen \&Unwin 2007.

[3] Organization for Economic Co-Operation and Development. Quality Time for Student: Learning in and Out of School. OECD Publishing 2001.

[4] Klibard, M. Herbert. Changing Course American Curriculum Reform in the Twentieth Century. New York: Teacher College Press 2002.

[5] Fesnema. The Use of Spatial Visualization in Mathematics by Boys and Girls. Journal for Research in Mathematics Education. 16 (3) 1995.

[6] Pitt, Sally Anne. Internal Audit Quality, developing A Quality Assurance and Improvement Program. New Jersey: John Willey and Sons, Inc 2014.

[7] Marzano, J. Robert. What Works in School, Translanting Research Into Action. Alexandria: ASCD 2011.

[8] Stolberg Tonie. Teaching Religion and Science, Effective pedagogy and practical approach for $R E$ Teachers. New York: Routledge 2011.

[9] Conklin, Wendy. Differentiating the Curriculum for Gifted Learners. Practical. California: Shell Education 2007.

[10] Smith, Emma. Analysing Underachievement in School. New York: Continuum 2005.

[11] Theodossin, Eduardo The Modular Market. Bristol: The Further Education Staff College 1986

[12] Betts, Mick and Robin, Smith. Developing the Credit based Modula Curriculum in Higher Education. Philadelphia: Falmer Press 2008.

[13] Pawlowski, M. Jan The Quality Adaptation Model: Adaptation and Adoption of the Quality Standard ISO/IEC 19796-1 for Learning , Education and Training. Essen, Germany: 
Isntitute for Computer Science and Business Info System 2007.

[14] Retalis, R. Kafalas. Quality Assurance procedures and $e-O D L$.Proceedings of the International
Conference on Network University and Elearning. Valencia: Spain 2003.

[15] Mathew, B.Miles and Michael, Huberman. ExpandedSourcebook, Qualitative Data Analyisis. London: Sage Publications 1994. 